Review

\title{
Is There a Place for Elastography in the Assessment of Chronic Kidney Disease?
}

\author{
Flaviu Bob ${ }^{\text {I,2 }}$ \\ ${ }^{\text {I }}$ Discipline of Nephrology, 2nd Department of Internal Medicine, "Victor Babes” University of Medicine and \\ Pharmacy, 30004I Timisoara, Romania; flaviu_bob@yahoo.com; Tel.: +40-748-33I-388 \\ ${ }^{2}$ Centre for Molecular Research in Nephrology and Vascular Disease, Faculty of Medicine, "Victor Babeș” University \\ of Medicine and Pharmacy, 30004I Timișoara, Romania \\ * Correspondence: ioanina.parlatescu@umfcd.ro; Tel.: +40-724-950-IO4
}

Submitted: 4 May 202I; Accepted: I4 June 202I; Published: 25 June 2021

\begin{abstract}
Renal elastography is a real-time ultrasound-based imaging method that can potentially be used in order to assess diffuse diseases of native kidneys. In order to find a place in the clinical practice for renal elastography, what is influencing the obtained results should be known. The kidney shear wave speed is influenced by different factors such as age, gender, measurement depth or urinary pressure. The relationship with renal function and also with renal fibrosis is different across different studies, with not all studies showing an increase in renal stiffness in more advanced renal diseases. However, the changes in renal blood flow seem to influence renal elastography, and a decrease in renal blood flow could be the cause of the decrease in the shear wave speed and could have a bigger influence on elastography compared to renal fibrosis. This paper provides a summary about the factors that seem to influence renal elastography and also regarding the limitations of this method according to the published studies thus far.
\end{abstract}

Keywords: kidney shear wave speed; renal stiffness; point shear wave elastography; shear wave speed imaging

How to cite: Bob, F. Is There a Place for Elastography in the Assessment of Chronic Kidney Disease?. Timisoara Med. 202I, 202I(I), 3; doi:10.35995/tmj20210103.

\section{Introduction}

Chronic kidney disease (CKD) has an increasing incidence and prevalence, and its progression is associated with high morbidity, mortality and increased health costs [I]. Therefore, it is very important to early diagnose CKD and to properly quantify the progression of the disease using different markers (biomarkers, histology, imaging).

Conventional ultrasound is used in order to assess the kidneys, but this method provides us with only a few pieces of quantifiable information regarding renal size and parenchyma thickness, which both decrease with the progression of CKD. Ultrasound also offers us some non-quantifiable data regarding the echogenicity of the renal cortex, which increases due to the progression of fibrosis in the advanced stages of CKD, when the kidneys become stiffer. 
In order to feel the consistency of the different tissues, we use palpation during the physical exam, a method that is quite difficult to perform on small kidneys. To obtain more detailed information that combines palpation with the ultrasound image, we could use a new ultrasound-based method, namely, elastography. This non-invasive method is already used in the clinical practice in the assessment of different organs, such as the liver-in both diffuse $[2,3]$ or focal lesions $[4]$ — spleen $[5,6]$, thyroid $[7,8]$ or prostate $[9]$.

Elasticity is an intrinsic property of a tissue that permits, after an initial stress, deformation, with a subsequent return to the normal shape. According to the technology used, there are the following methods of measuring the elasticity of tissues:

\section{Strain Elastography (SE)}

This method is based on manual compression and measures the strain or displacement of the tissue. The method can be used only for superficial kidneys, and particularly renal transplants [io].

\section{Shear Wave Elastography}

This method basically measures the tissue shear wave speed or velocity (SWV). The SWV (expressed in $\mathrm{m} / \mathrm{s}$ ) correlates with Young's modulus $(\mathrm{kPa})$, which is a measure of tissue stiffness; thus, a stiffer tissue leads to a faster SWV.

(a) Transient Elastography (TE) is based on controlled external vibration that generates shear waves. This method is mainly used for assessing the stiffness of liver tissue (Fibroscan). The use of TE in the kidneys is difficult, and very few studies have been published using this method because the heterogeneous kidney morphology can affect the performed measurements [II].

(b) Acoustic radiation force impulse (ARFI) excitation is based on focused acoustic radiation force pushing pulses that generate shear waves inside the organ. These shear waves propagate and are progressively attenuated due to their absorption in the soft tissue, and their speed of propagation can be measured, resulting in the SWV. The advantage of ARFI is based on the fact that the same transducer is used to generate shear waves and to image their propagation, and it is integrated into a standard ultrasound system [I2]. There are two types of ARFI:

- Point shear wave elastography ( $p S W E$ ). The result is an average value inside a region of interest (ROI). The systems/machines that use pSWE are as follows: Virtual Touch Quantification (Siemens S2ooo, S30oo) (Figure I), and Elastography Point Quantification (Phillips Affiniti) (Figure 2). 


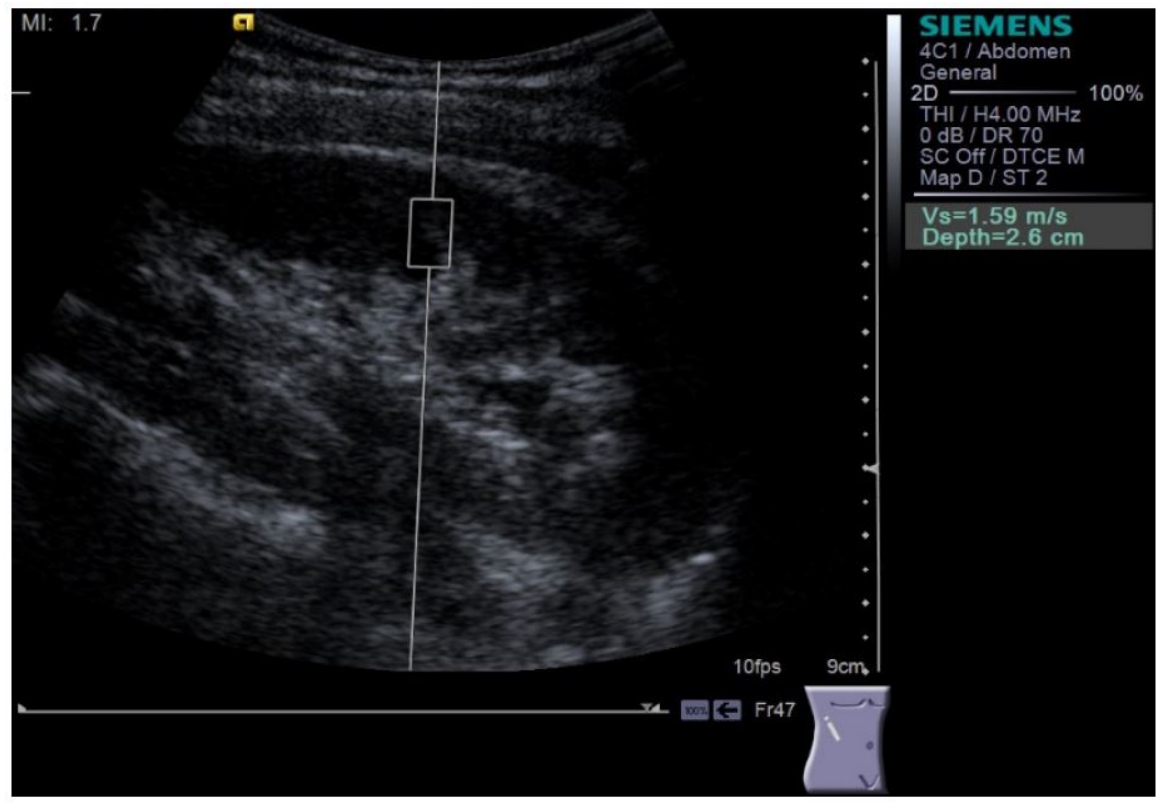

Figure I. Renal elastography using a pSWE method: Siemens Acuson S20oo ${ }^{\mathrm{TM}}$ ultrasound system using Virtual Touch $^{\text {TM }}$ Tissue Quantification (VTQ) application, software version 2.o (Siemens AG, Erlangen, Germany), with a ${ }_{4} \mathrm{CI}$ transducer. Results of kidney SWE are expressed in $\mathrm{m} / \mathrm{s}$.

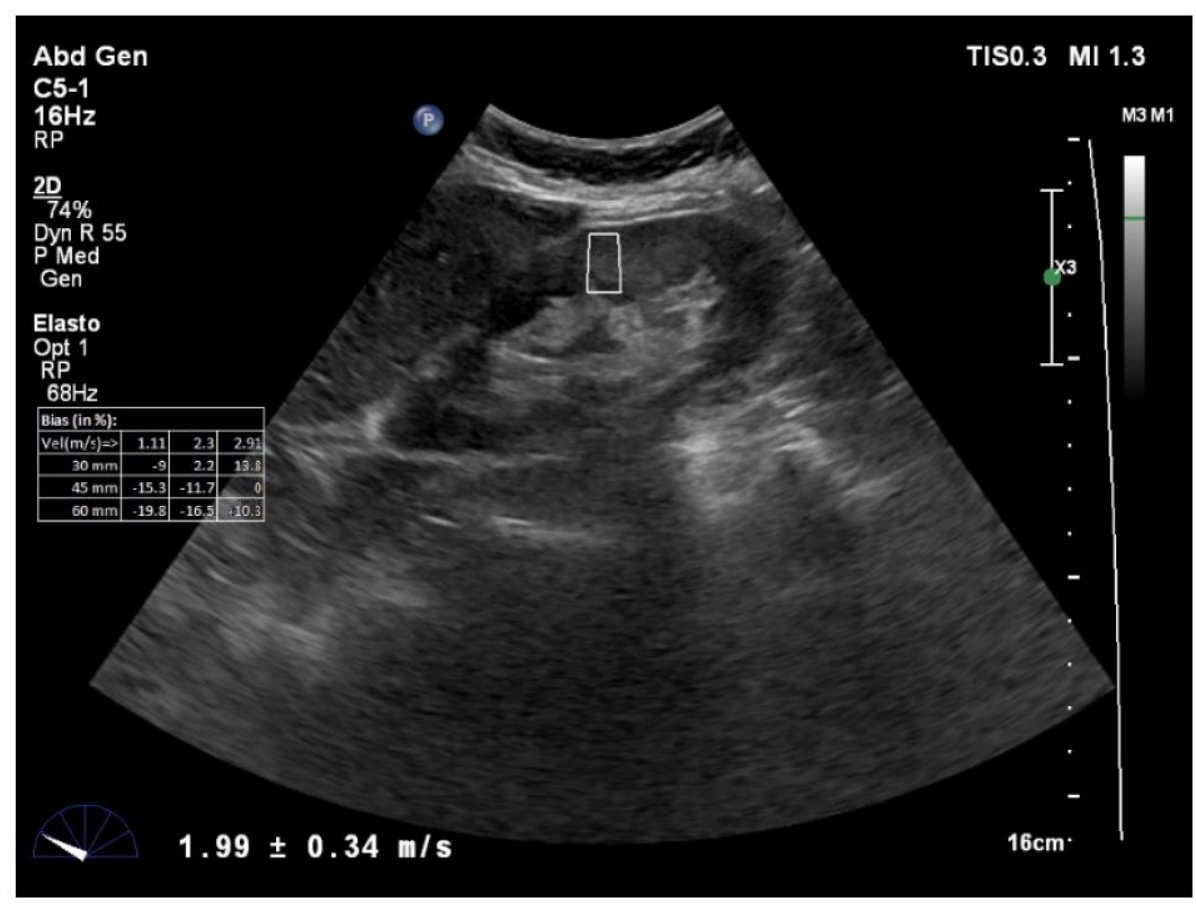

Figure 2. Renal elastography using a pSWE method: Phillips Affiniti ultrasound system using an Elastography Point Quantification system with a ${ }_{4} \mathrm{CI}$ transducer. Results of kidney SWE are expressed in $\mathrm{m} / \mathrm{s}$.

- Shear wave speed imaging (2D-SWE). The information is reported as a color-coded map mosaic inside the ROI. Systems that use this method are as follows: the 2 D-SWE-SSI technique (Aixplorer) (Figure 3), and 2D-SWE-GE (General Electric) (Figure 4). 


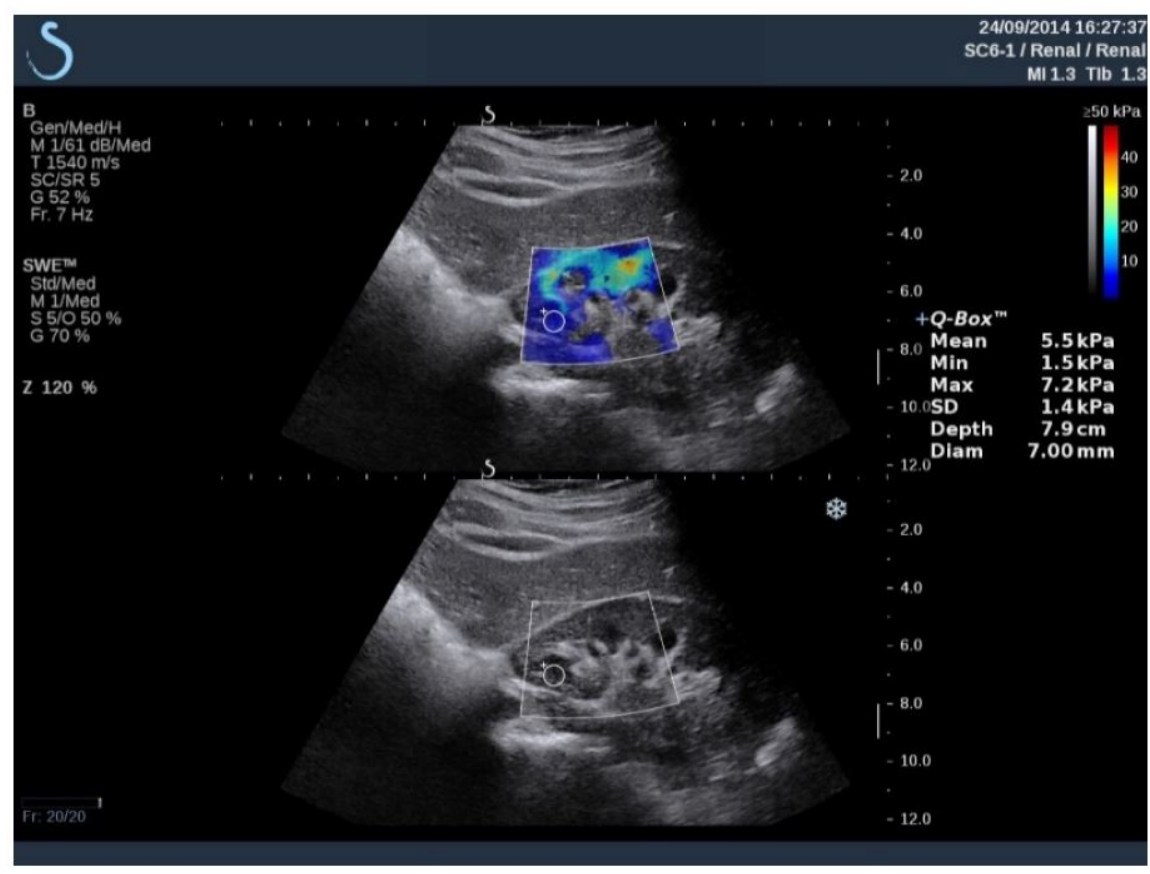

Figure 3. Renal elastography using a 2D-SWE method: SuperSonic Imagine Aixplorer ${ }^{\circledR}$ ShearWave ${ }^{\mathrm{TM}}$ elastography $^{-}$ system with a SuperCurved ${ }^{\mathrm{TM}}$ SC6-I transducer. Results of kidney stiffness are expressed in kPa.

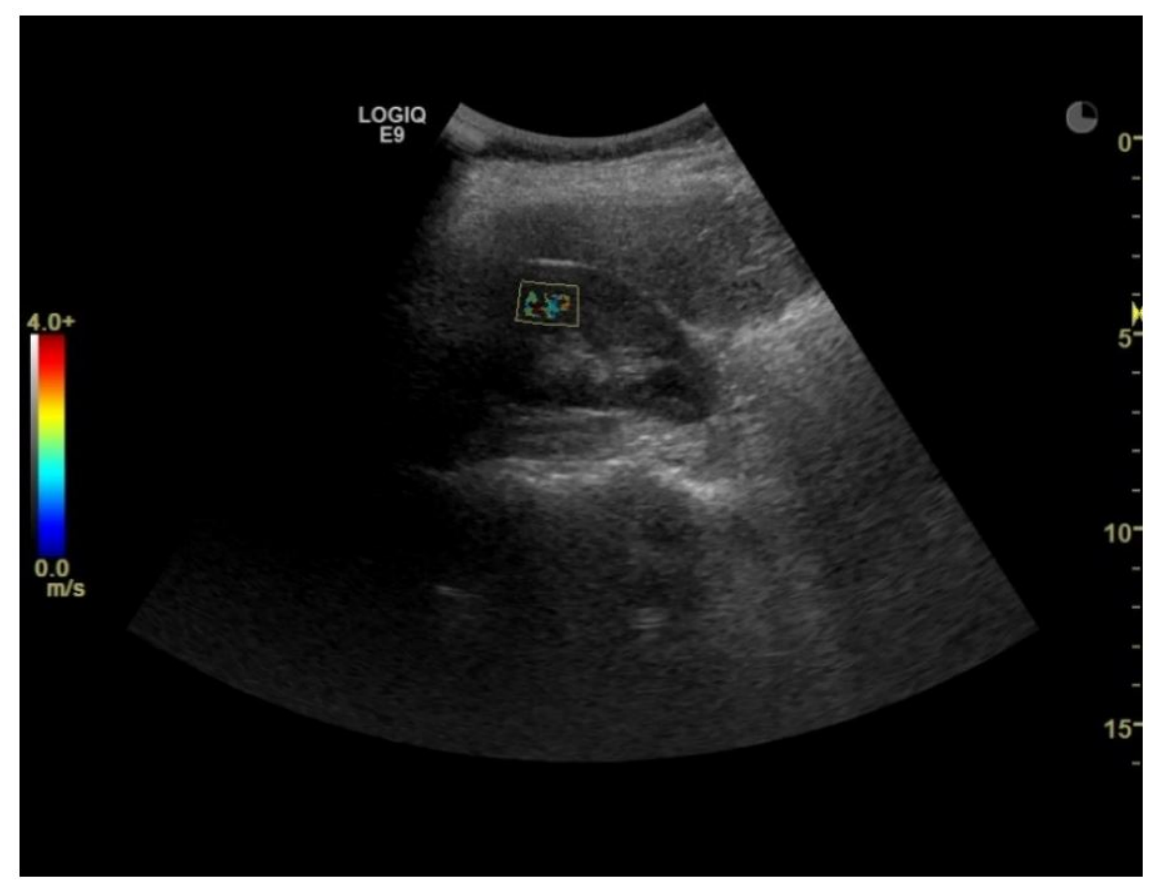

Figure 4. Renal elastography using a 2D-SWE method: Logiq E9- GE ultrasound system.

For the assessment of native kidneys, especially for diffuse renal diseases, the last two mentioned methods (pSWE and 2D-SWE) seem to be suitable and will be referred to in this article. 


\section{What Is Influencing Renal Shear Wave Velocity?}

Renal elastography ( $\mathrm{pSWE}$ or $2 \mathrm{D}-\mathrm{SWE}$ ) should be performed with the patient in the lateral decubitus position and being asked to stop breathing for a moment, in order to minimize breathing motion. The image obtained is a normal ultrasound image, and there is the region of interest (ROI) superimposed on it, inside which the kidney shear wave speed is measured (Figures I-4). The ROI has a maximum depth of $8 \mathrm{~cm}$ and should be placed in the mid-portion of the renal parenchyma. The result is displayed on the screen and is expressed either in $\mathrm{m} / \mathrm{s}$ or in $\mathrm{kPa}$. When using a standardized approach of the native kidneys, the method proved to be reproducible between observers $[\mathrm{I} 3, \mathrm{I} 4]$.

The normal kidney shear wave speed measured at the cortical level of the kidneys is quite different according to different studies and depending on the elastography system that has been used. Thus, for pSWE, the normal values range between 2.15 and $2.54 \mathrm{~m} / \mathrm{s}$ (for the VTQ system), while for $2 \mathrm{D}-\mathrm{SWE}$, they range between 1.23 and I. $54 \mathrm{~m} / \mathrm{s}[\mathrm{Is}]$.

The kidney shear wave speed seems to be influenced by age, with a decrease in renal stiffness in older subjects, and also by gender, with men showing lower values compared to women [16,17]. Another influencing factor is the measurement depth, with the kidney shear wave speed decreasing with increasing depth [15,18,19].

Another factor that could influence the SWV is the urinary pressure. There are some published studies that addressed this topic, but the results are not consistent. In a study performed on 5 I children with different degrees of hydronephrosis, the SWV was increased in the kidneys of affected children compared to controls [20]. In another study performed on 88 children, the SWV decreased with increasing grades of vesicoureteral reflux [2I]. A third smaller study (37 children) using shear wave elastography was not able to discriminate between obstructive and unobstructive hydronephrosis [22].

For the clinical practice, it would be of great importance to find out what pathological changes in kidneys with chronic kidney disease influence the SWV. From the studies performed on the liver, it is known that liver stiffness increases with the progression of liver disease, due to fibrosis. As the histological background of chronic kidney disease is renal fibrosis, it can be hypothesized that similar changes occur in the kidneys, and therefore the progression of kidney disease should lead to an increase in the SWV. However, the studies published thus far that compare elastography performed in patients with CKD with normal controls show some interesting aspects.

There are studies that confirm the initial hypothesis of significantly increased SWV values in patients with CKD compared to normal controls [23-27]. However, other authors do not confirm these results and the initial hypothesis (of the increase in renal stiffness with the presence or progression of renal disease) [15,28,29]. Moreover, it has been shown that kidney shear wave speed values are significantly decreased in patients with a decreased glomerular filtration rate (eGFR) [30-32]. Despite the statistically significant correlation between the kidney SWV and the eGFR that is mentioned in some studies, no significant differences could be found between the SWV levels in the different stages of CKD, and the efficient use of elastography in order to differentiate between different stages of CKD could not be proven yet [33,34].

The attempts made thus far to establish cut-off values of the kidney SWV for the diagnosis of CKD are mainly directed towards more advanced stages of CKD (stage $\mathrm{G}_{3}$ ). Thus, pSWE using the VTQ system had a sensitivity of $67.4 \%$ and a specificity of $67.8 \%$ in predicting an eGFR of $<60 \mathrm{~mL} / \mathrm{min}$ in patients with diabetic kidney disease with a kidney SWV of $2.32 \mathrm{~m} / \mathrm{s}$ or less [35]. More reliable results have been reported with 
another elastography system-2D-SWE from GE-which, for an SWE cut-off value of $1.47 \mathrm{~m} / \mathrm{s}$ or less, could predict the presence of CKD, with a sensitivity of $89.2 \%$ and a specificity of $76.9 \%$ [33].

The diagnostic accuracy of elastography is higher if the results of the kidney SWV are combined with other elements. In a study of patients with diabetic kidney disease, it was shown that combining kidney SWV values obtained using the Elast-PQ method with the urinary albumin/creatinine ratio and diabetes duration, based on a logistic regression model, significantly improved the accuracy of diagnosing early diabetic kidney disease compared to the use of the predictors independently [36].

\section{Correlation between Elastography and Histological Parameters}

The surprising correlations mentioned above, such as the decrease in many of the published studies of the kidney SWV in more advanced stages of renal disease, raise the question concerning whether there is a relationship between elastography and histological changes at the level of the kidney, and if fibrosis influences elastography measurements.

Most of the studies that compare elastography with histological parameters were performed in renal transplant recipients [9,37-43]. In native kidneys, there are studies using different elastography systems (VTQ, Elast-PQ) that show a statistically significant increase in the kidney SWV in patients with more severe renal (glomerular and tubulointerstitial) histological changes $[22,44]$. In a study performed using the $2 \mathrm{D}$-SWE-SSI elastography method, it has been shown not only that kidney stiffness positively statistically significantly correlates with the degree of glomerulosclerosis and tubulointerstitial fibrosis but also that patients with a lower kidney SWV showed a better response to corticotherapy [45].

However, not all published studies show similar results regarding the relationship between kidney elastography and histological changes. There is one study that shows no statistically significant correlation of the kidney SWV with the studied histological parameters (glomerulosclerosis index, tubular atrophy, interstitial fibrosis) [46]. In another study performed in living kidney transplantation donors, in whom elastography was performed before nephrectomy and renal biopsies before implantation, there were no statistically significant correlations between the histological parameters (interstitial fibrosis and tubular atrophy) and the kidney SWV (although the kidneys with more pronounced interstitial fibrosis had a non-significant lower SWV) [16].

In a study performed on 163 patients with $\mathrm{CKD}$ and 32 healthy volunteers by $\mathrm{Hu} \mathrm{Q}$. et al., it was shown that subjects with an impaired histological score showed a reduced kidney SWV [30]. Similar results were reported in a smaller pilot study performed on patients with glomerulonephritis, in whom the presence of tubulo-interstitial fibrosis or of arteriolar hyalinosis was associated with significantly decreased values of the SWV [47]. In another study performed in patients with IgA nephropathy, it was shown that the kidney SWV was significantly lower in more severe diseases, but combining the kidney SWV with conventional ultrasound features (renal length, parenchymal thickness, resistance index) improved the prediction of the different fibrosis stages [48].

The lack of consistency between the different results of studies that compared histology with elastography of the kidney could be due to the heterogeneous patterns of histologic involvement in different types of renal disease (glomerular, vascular and tubulointerstitial). This could also lead to the conclusion that other factors besides histological changes (renal fibrosis) are involved in influencing the SWV at the level of the kidney. 


\section{The Question of Renal Blood Flow}

As the vascularization of the kidney is increased, it is possible that the SWV is influenced by renal blood flow [49,50]. There are experimental data available that emphasize this hypothesis. The increase in renal pressure by cannulating an ex vivo kidney and introducing saline showed a significant increase in renal stiffness measured using $2 \mathrm{D}-\mathrm{SWE}$ (Aixplorer) [ $\left[\mathrm{s}_{1}\right]$. Moreover, after ligation of the renal artery in experimental animal kidneys, a decrease in the SWV is noted, while after ligation of the renal vein, an increase in the SWV occurs $[52,53]$.

These experimental data have been confirmed in human kidneys as well. In a case report of a patient with renal vein thrombosis, it was shown that the SWV was increased in the kidney with renal vein thrombosis compared to the contra-lateral kidney [54]. A very important piece of evidence sustaining the renal blood flow hypothesis is the paper published by Asano et al. that shows that a low kidney SWV was obtained in patients with a high brachial-ankle pulse wave velocity (PWV). This means that in patients in whom there is a progression of arteriosclerosis in the large vessels (high PWV), the kidney SWV is low, probably explained by the decreased renal blood flow in these patients [47]. These results were confirmed in another study performed in patients with diabetic kidney disease that showed a negative, statistically significant correlation between the KSWS, on the one hand, and the PWV and aortic augmentation index, on the other hand [55].

It is possible that the relationship between renal blood flow and renal stiffness explains the results of a study that showed that patients with a lower kidney SWV had a higher risk of bleeding after renal biopsy [56]. Another study that is in favor of the hypothesis that renal hemodynamics influences renal stiffness was performed by Lee et al. on renal transplant recipients. The authors showed that in patients with a low kidney weight/body weight ratio, in which an adaptive glomerular hyperfiltration occurs, the result is an increased kidney SWV [39]. In another study performed by Wang et al. in patients with gestational hypertension, characterized by renal hypoperfusion, it was shown that a high blood pressure was associated with a low renal elasticity [57].

The relationship between the results of renal elastography and renal blood flow has also been confirmed using two-dimensional time-harmonic ultrasound elastography, a method that combines $2 \mathrm{D}-\mathrm{SWE}$ with the use of a vibration bed generating continuous vibrations, thus permitting deeper measurements $(13 \mathrm{~cm})$ and obtaining elastograms that cover a full field (the entire kidney and not just an ROI) [58]. Using this type of device, Grossman et al. showed that in patients with glomerulonephritis (even in CKD stage I), the kidney SWV was significantly lower compared to normal controls, and the negative, statistically significant correlations with the resistive index might indicate that renal blood flow influenced the obtained results [59].

Thus, a renal blood flow decrease could be the cause of the decrease in the SWV and could have a bigger influence on the SWV compared to renal fibrosis. Intrarenal blood flow is decreased due to the progression of fibrosis, having opposite effects on the renal SWV, a fact that could explain why renal fibrosis is not associated with an increase in renal stiffness in some of the cited studies (see Table I) $[30,46,47]$. 
Table I. Main published studies of elastography in native kidneys.

\begin{tabular}{|c|c|c|c|c|}
\hline Study & $\begin{array}{l}\text { Elastography } \\
\text { Method }\end{array}$ & $\begin{array}{l}\text { Patient Population (Number, Type of } \\
\text { Subjects) }\end{array}$ & Histology & $S W V$ in $C_{K D}^{*}$ \\
\hline Guo LH et al., 2013 [17] & VTQ & $\begin{array}{l}64 \text { CKD patients/ } \\
327 \text { healthy subjects }\end{array}$ & no & decrease \\
\hline Hu Q et al., 20I4 [3I] & VTQ & $\begin{array}{l}\text { 163 CKD patients/ } \\
32 \text { healthy subjects }\end{array}$ & yes & decrease \\
\hline Yu N et al., 2014 [24] & VTQ & $\begin{array}{l}\text { I2O diabetic patients/ } \\
\text { 30 healthy subjects }\end{array}$ & no & increase \\
\hline Asano K et al., 20I4 [49] & VTQ & $\begin{array}{l}309 \text { CKD patients/ } \\
\text { I4 healthy subjects }\end{array}$ & no & decrease \\
\hline Wang L et al., 20I4 [46] & VTQ & 45 CKD patients & yes & no relationship \\
\hline Cui G et al., 2014 [23] & VTQ & $76 \mathrm{CKD}$ patients & yes & increase \\
\hline Bob F. et al., 20I5 [32] & VTQ & $\begin{array}{l}46 \text { CKD patients/ } \\
58 \text { healthy subjects }\end{array}$ & no & decrease \\
\hline Samir AE et al., 2015 [26] & 2D-SWE-SSI & $\begin{array}{l}\text { 25 CKD patients/ } \\
20 \text { healthy subjects }\end{array}$ & no & increase \\
\hline Bob F. et al. (2); 2015 [47] & VTQ & 20 CKD patients & yes & moderate decrease \\
\hline Alan B. et al., 2016 [30] & VTQ & $\begin{array}{l}76 \text { coronary artery disease patients/ } \\
79 \text { healthy subjects }\end{array}$ & no & decrease \\
\hline Bob F. et al., 2017 [35] & VTQ & $\begin{array}{l}\text { 8o diabetic kidney disease patients/ } \\
84 \text { healthy subjects }\end{array}$ & no & decrease \\
\hline $\begin{array}{l}\text { Bilgici MC. et al., } 2017 \\
\text { [28] }\end{array}$ & VTQ & $\begin{array}{l}30 \text { CKD patients/ } \\
38 \text { healthy subjects_-pediatric patients }\end{array}$ & no & decrease \\
\hline Sasaki Y et al., 2018 [33] & VTQ & I87 CKD patients & no & no relationship \\
\hline Yang X. et al., 2018 [25] & VTQ & $\begin{array}{l}90 \text { idiopathic nephrotic syndrome CKD } \\
\text { patients/ } \\
30 \text { healthy subjects }\end{array}$ & no & increase \\
\hline Grosu et al., 2018 [29] & Elast-PQ & $\begin{array}{l}\text { IO2 CKD patients/ } \\
22 \text { healthy subjects }\end{array}$ & no & decrease \\
\hline Liu QY. et al., 2019 [36] & Elast-PQ & $\begin{array}{l}69 \text { diabetic kidney disease patients/ } \\
40 \text { diabetic controls }\end{array}$ & no & increase \\
\hline Hu Q. et al., 2019 [48] & VTQ & $\begin{array}{l}\text { I46 IgA nephropathy patients/ } \\
39 \text { healthy volunteers }\end{array}$ & yes & decrease \\
\hline Grosu et al., 2019 [34] & 2D-SWE-GE & $\begin{array}{l}42 \text { CKD patients/ } \\
\text { so healthy subjects }\end{array}$ & no & decrease \\
\hline $\begin{array}{l}\text { Sumbul HE et al., } 2020 \\
{[27]}\end{array}$ & Elast-PQ & $\begin{array}{l}\text { I25 diabetic, prediabetic patients and } \\
\text { controls }\end{array}$ & no & increase \\
\hline Yang X et al.2020 [45] & 2D-SWE-SSI & $\begin{array}{l}\text { I2O idiopathic nephrotic syndrome-CKD } \\
\text { patients }\end{array}$ & yes & increase \\
\hline Lee et al., 202I [I8] & VTQ & $\begin{array}{l}73 \text { (biopsies of kidney donors before } \\
\text { transplant) }\end{array}$ & yes & $\begin{array}{l}\text { no (tendency to } \\
\text { decrease) }\end{array}$ \\
\hline Leong SS et al., 202I [44] & ElastPQ & $75 \mathrm{CKD}$ patients & yes & increase \\
\hline
\end{tabular}

* The terms "increase" and "decrease" represent a statistically significant change in the SWV in CKD compared to healthy subjects, or in more severe CKD compared to less advanced stages. 


\section{The Difficulty of the Use of Elastography in Kidneys}

As shown in the presented studies, the results obtained using elastography in native kidneys for the assessment of diffuse diseases are quite heterogenous. Although the assessment, when using pSWE or $2 \mathrm{D}-\mathrm{SWE}$, has certain advantages such as the fact that the image is obtained in real time, without a special prior preparation of the subjects and without complications of the procedure, the use of elastography in the assessment of the kidneys is more difficult compared to the use in other organs.

First of all, the difficult interpretation of the results is due to the architecture of the renal tissue, characterized by a high degree of anisotropy, which has an impact on the measured kidney SWV [6o]. Thus, it is important how the ultrasound main axis enters the kidneys, either parallel to the renal pyramid axis, when the ROI is established in the mid-portion of the renal parenchyma, or perpendicular to the renal pyramid axis, when the ROI is established in the superior or inferior renal pole [5I]. The shear wave speed obtained in the two situations is different. However, it has been proposed recently to benefit from the anisotropy, to standardize the variation in the SWE in the kidneys and to use the obtained anisotropic ratio as a diagnostic and monitoring marker in CKD [6r].

A problem of performing elastography in the kidneys is the fact that the dimension of the ROI is fixed at I $\mathrm{cm}$. If the measurements are performed at the level of the parenchyma, the method will be difficult to use in patients with a reduced size of the parenchyma, namely, in patients with advanced CKD. Despite the fact that apparently the stiffness of the medulla is lower compared to that of the cortex [62], in practice, it is difficult to differentiate between the cortex and the medulla, also because of the size of the ROI.

It is important, however, to mention another aspect related to the particularities of renal elastography: the importance of reverberation artifacts, which are common ultrasound artifacts and occur when a sound pulse reverberates back and forth between two strong parallel reflectors. Therefore, when performing liver elastography, there is a recommendation to establish the ROI I.5-2 cm beneath the capsule in order to avoid these artifacts that lead to increased measured values [63]. Regarding renal elastography, because of the architecture of the kidneys, it is difficult to avoid reverberation artifacts, due to the necessity to establish the ROI just beneath the renal capsule.

Another problem is related to the compression of the transducer. In a study published by Correas, it was shown that the cortex stiffness increases from 34 to $92 \mathrm{kPa}$ after increasing the compression with the transducer [63]. In practice, it is possible that if the kidneys are superficial, the different applied transducer force, which cannot be quantified, could intervene, leading to different SWVs.

Another limitation of this method is the fact that the different methods that are available, and that have been mentioned previously, come from different providers, and no correlation tables are available in order to compare the results obtained with different transducers from different manufacturers. A step towards a better understanding of the different systems would be an analysis of raw data. It has recently been pointed out in a study performed by Richard Barr, who analyzed raw data of three different machines (Siemens, Phillips and Aixplorer), that in order to obtain more accurate renal stiffness data from an elastographic system, improved processing algorithms are needed [64].

\section{Conclusion}

Elastography is a real-time imaging method that could be useful in the assessment of the kidneys, with the technique having a good reproducibility between observers and also showing a good technical performance 
for the measurement of renal parenchymal stiffness [12]. However, despite this fact, there are multiple factors that influence renal stiffness results obtained with the different elastography devices, such as age, gender, measurement depth, urinary pressure, fibrosis and, especially, renal blood flow (Figure 5 ). This is why the relationship between the kidney SWV and renal function is not completely established.

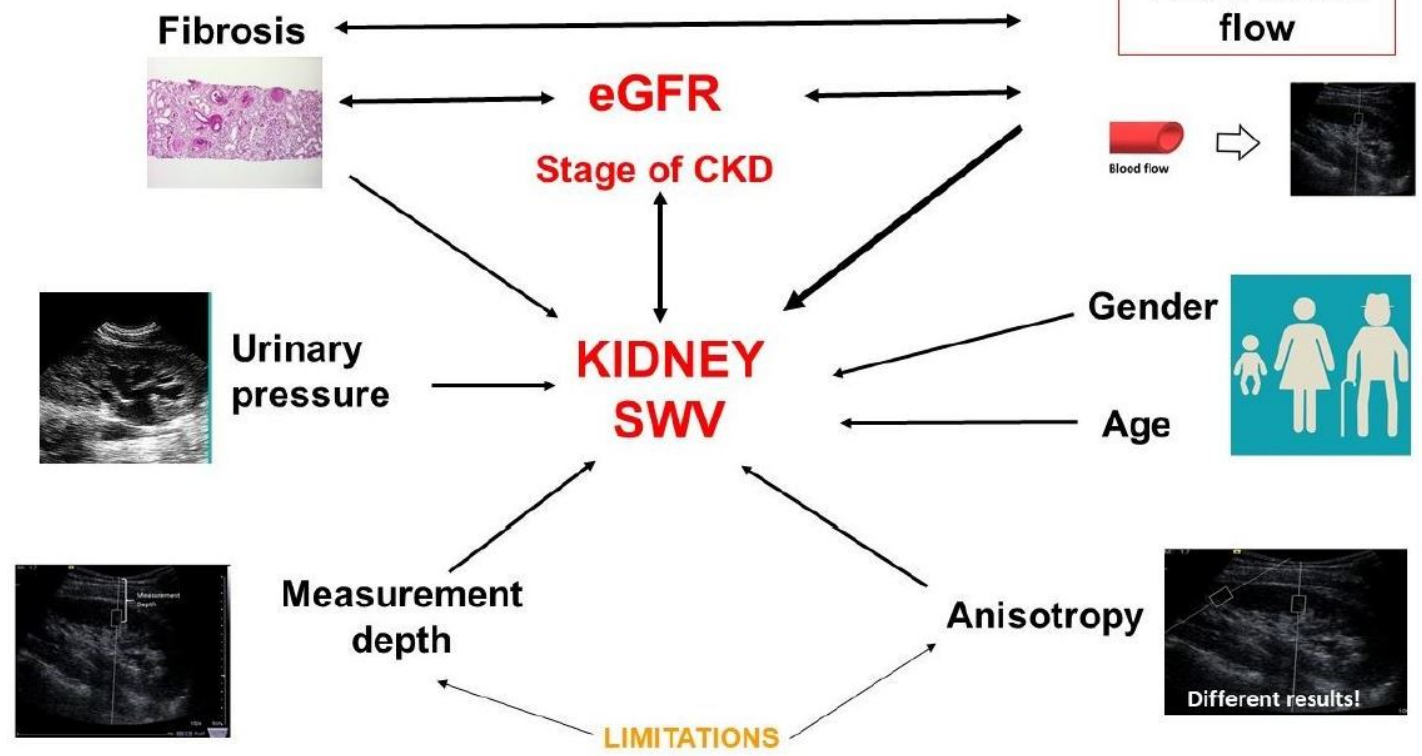

Figure 5. Kidney shear wave velocity (SWV) is influenced by multiple factors.

Considering these aspects, at the moment, no evidence-based recommendations can be offered for the use of this method in native kidneys [II]. Therefore, more extensive studies are needed in order to establish which factors influence the kidney SWV in patients with CKD, and thus to find the place and indication of renal elastography in the clinical practice.

Author Contributions: Conceptualization, methodology, formal analysis, investigation, resources, data curation, writing and supervision, F.B.

Funding: This research received no external funding.

Acknowledgments: The personal research cited in this review and the images inserted in this article were carried out with the support of the Center of Elastography of the University of Medicine and Pharmacy "Victor Babes" Timisoara, Romania.

Conflicts of Interest: The author declares no conflict of interest.

\section{References}

I. Turner, N.; Lameire, N.; Goldsmith, D.J.; Winearls, C.G.; Himmelfarb, J.; Remuzzi, G. Oxford Textbook of Clinical Nephrology, 4th ed.; Oxford University Press: Oxford, UK, 2016.

2. Bota, S.; Herkner, H.; Sporea, I.; Salzl, P.; Sirli, R.; Neghina, A.M.; Peck-Radosavljevic, M. Meta-analysis: ARFI elastography versus transient elastography for the evaluation of liver fibrosis. Liver Int. 2013, 33, II38-II47. [CrossRef]

3. Nierhoff, J.; Ortiz, A.A.C.; Herrmann, E.; Zeuzem, S.; Friedrich-Rust, M. The efficiency of acoustic radiation force impulse imaging for the staging of liver fibrosis: A meta-analysis. Eur. Radiol. 2013, 23, 3040-3053. [CrossRef] 
4. Ying, L.; Lin, X.; Xie, Z.-L.; Tang, F.-Y.; Hu, Y.-P.; Shi, K.-Q. Clinical utility of acoustic radiation force impulse imaging for identification of malignant liver lesions: A meta-analysis. Eur. Radiol. 2012, 22, 2798-2805. [CrossRef]

5. Bota, S.; Sporea, I.; Şirli, R.; Focsa, M.; Popescu, A.; Dănilă, M.; Strain, M. Can ARFI elastography predict the presence of significant esophageal varices in newly diagnosed cirrhotic patients? Ann. Hepatol. 2012, II, 519-525. [CrossRef]

6. Takuma, Y.; Nouso, K.; Morimoto, Y.; Tomokuni, J.; Sahara, A.; Toshikuni, N.; Takabatake, H.; Shimomura, H.; Doi, A.; Sakakibara, I.; et al. Measurement of Spleen Stiffness by Acoustic Radiation Force Impulse Imaging Identifies Cirrhotic Patients With Esophageal Varices. Gastroenterol. 2or3, I44, 92-IoI. [CrossRef]

7. Zhang, B.; Ma, X.; Wu, N.; Liu, L.; Liu, X.; Zhang, J.; Yang, J.; Niu, T. Shear wave elastography for differentiation of benign and malignant thyroid nodules: A meta-analysis. J. Ultrasound Med. 2013, 32, 2163-2169. [CrossRef]

8. Hou, X.-J.; Sun, A.-X.; Zhou, X.-L.; Ji, Q.; Wang, H.-B.; Wei, H.; Sun, J.-W.; Liu, H. The application of Virtual Touch tissue quantification (VTQ) in diagnosis of thyroid lesions: A preliminary study. Eur. J. Radiol. 2or3, 82, 797-8oI. [CrossRef]

9. Zhai, L.; Madden, J.; Foo, W.-C.; Mouraviev, V.; Polascik, T.J.; Palmeri, M.L.; Nightingale, K.R. Characterizing Stiffness of Human Prostates Using Acoustic Radiation Force. Ultrason. Imaging 2oro, 32, 20I-213. [CrossRef]

Io. Qi, R.; Yang, C.; Zhu, T. Advances of Contrast-Enhanced Ultrasonography and Elastography in Kidney Transplantation: From Microscopic to Microcosmic. Ultrasound Med. Biol. 202I, 47, 177-184. [CrossRef]

II. Sommerer, C.; Scharf, M.; Seitz, C.; Millonig, G.; Seitz, H.K.; Zeier, M.; Mueller, S. Assessment of renal allograft fibrosis by transient elastography. Transpl. Int. 2013, 26, 545-551. [CrossRef]

I2. Shiina, T.; Nightingale, K.R.; Palmeri, M.L.; Hall, T.J.; Bamber, J.C.; Barr, R.G.; Castera, L.; Choi, B.I.; Chou, Y.-H.; Cosgrove, D.; et al. WFUMB Guidelines and Recommendations for Clinical Use of Ultrasound Elastography: Part I: Basic Principles and Terminology. Ultrasound Med. Biol. 2o15, 4I, II26-II47. [CrossRef]

I3. Bob, F.; Bota, S.; Sporea, I.; Sirli, R.; Petrica, L.; Schiller, A. Kidney Shear Wave Speed Values in Subjects with and without Renal Pathology and Inter-Operator Reproducibility of Acoustic Radiation Force Impulse Elastography (ARFI) - Preliminary Results. PLoS ONE 2014, 9, eIr376r. [CrossRef]

I4. Hwang, J.; Kim, H.W.; Kim, P.H.; Suh, C.H.; Yoon, H.M. Technical Performance of Acoustic Radiation Force Impulse Imaging for Measuring Renal Parenchymal Stiffness. J. Ultrasound Med. 2o2I. [CrossRef]

I5. Săftoiu, A.; Gilja, O.H.; Sidhu, P.; Dietrich, C.F.; Cantisani, V.; Amy, D.; Bachmann-Nielsen, M.; Bob, F.; Bojunga, J.; Brock, M.; et al. The EFSUMB Guidelines and Recommendations for the Clinical Practice of Elastography in Non-Hepatic Applications: Update 2018. Ultraschall der Med. Eur. J. Ultrasound 2019, 40, 425-453. [CrossRef]

I6. Bota, S.; Bob, F.; Sporea, I.; Şirli, R.; Popescu, A. Factors that Influence Kidney Shear Wave Speed Assessed by Acoustic Radiation Force Impulse Elastography in Patients without Kidney Pathology. Ultrasound Med. Biol. 20I5, 4I, I-6. [CrossRef] [PubMed]

17. Guo, L.-H.; Xu, H.-X.; Fu, H.-J.; Peng, A.; Zhang, Y.-F.; Liu, L.-N. Acoustic Radiation Force Impulse Imaging for Noninvasive Evaluation of Renal Parenchyma Elasticity: Preliminary Findings. PLoS ONE 2013, 8, e68925. [CrossRef]

I8. Lee, A.; Joo, D.J.; Han, W.K.; Jeong, H.J.; Oh, M.J.; Kim, Y.S.; Oh, Y.T. Renal tissue elasticity by acoustic radiation force impulse. Medicine 202I, I0o, e2356I. [CrossRef] [PubMed]

19. Zhao, H.; Song, P.; Urban, M.W.; Kinnick, R.R.; Yin, M.; Greenleaf, J.F.; Chen, S. Bias observed in time-offlight shear wave speed measurements using radiation force of a focused ultrasoundbeam. Ultrasound Med. Biol. 20II, 370, 1884-1892. [CrossRef] [PubMed]

2o. Sohn, B.; Kim, M.-J.; Han, S.W.; Im, Y.J.; Lee, M.-J. Shear wave velocity measurements using acoustic radiation force impulse in young children with normal kidneys versus hydronephrotic kidneys. Ultrasonography 2or4, 33, II6-I2I. [CrossRef] [PubMed]

2I. Göya, C.; Hamidi, C.; Ece, A.; Okur, M.H.; Taşdemir, B.; Çetinçakmak, M.G.; Hattapoğlu, S.; Teke, M.; Şahin, C. Acoustic radiation force impulse (ARFI) elastography for detection of renal damage in children. Pediatr. Radiol. 2015, 45, 55-61. [CrossRef] [PubMed]

22. Dillman, J.R.; Smith, E.A.; Davenport, M.S.; DiPietro, M.A.; Sanchez, R.; Kraft, K.H.; Brown, R.K.; Rubin, J.M. Can Shear-Wave Elastography be Used to Discriminate Obstructive Hydronephrosis from Nonobstructive Hydronephrosis in Children? Radiology 2015, 277, 259-267. [CrossRef] [PubMed]

23. Cui, G.; Yang, Z.; Zhang, W.; Li, B.; Sun, F.; Xu, C.; Wang, K. Evaluation of acoustic radiation force impulse imaging for the clinicopathological typing of renal fibrosis. Exp. Ther. Med. 2or4, 7, 233-235. [CrossRef]

24. Yu, N.; Zhang, Y.; Xu, Y. Value of Virtual Touch Tissue Quantification in Stages of Diabetic Kidney Disease. J. Ultrasound Med. 2or4, 33, 787-792. [CrossRef] [PubMed]

25. Yang, X.; Yu, N.; Yu, J.; Wang, H.; Li, X. Virtual Touch Tissue Quantification for Assessing Renal Pathology in Idiopathic Nephrotic Syndrome. Ultrasound Med. Biol. 2or8, 44, 1318-1326. [CrossRef]

26. Samir, A.E.; Allegretti, A.S.; Zhu, Q.; Dhyani, M.; Anvari, A.; Sullivan, D.A.; Trottier, C.A.; Dougherty, S.; Williams, W.W.; Babitt, J.L.; et al. Shear wave elastography in chronic kidney disease: A pilot experience in native kidneys. BMC Nephrol. 2ois, I6, II9. [CrossRef] 
27. Sumbul, H.; Koc, A.; Gulumsek, E. Renal cortical stiffness is markedly increased in pre-diabetes mellitus and associated with albuminuria. Singap. Med.J. 2020, 6I, 435-442. [CrossRef]

28. Bilgici, M.C.; Bekci, T.; Genc, G.; Tekcan, D.; Tomak, L. Acoustic Radiation Force Impulse Quantification in the Evaluation of Renal Parenchyma Elasticity in Pediatric Patients With Chronic Kidney Disease: Preliminary Results. J. Ultrasound Med. 2017, 36, 1555-156I. [CrossRef]

29. Grosu, I.; Bob, F.; Sporea, I.; Popescu, A.; Şirli, R.; Schiller, A. Correlation of Point Shear Wave Velocity and Kidney Function in Chronic Kidney Disease. J. Ultrasound Med. 2018, 37, 2613-2620. [CrossRef]

3o. Alan, B.; Göya, C.; Aktan, A.; Alan, S. Renal acoustic radiation force impulse elastography in the evaluation of coronary artery disease. Acta Radiol. 2o17, 58, 156-163. [CrossRef]

3I. Hu, Q.; Wang, X.-Y.; He, H.-G.; Wei, H.-M.; Kang, L.-K.; Qin, G.-C. Acoustic Radiation Force Impulse Imaging for Non-Invasive Assessment of Renal Histopathology in Chronic Kidney Disease. PLoS ONE 2or4, 9, eII505I. [CrossRef]

32. Bob, F.; Bota, S.; Sporea, I.; Sirli, R.; Popescu, A.; Schiller, A. Relationship between the estimated glomerular filtration rate and kidney shear wave speed values assessed by acoustic radiation force impulse elastography: A pilot study. J. Ultrasound Med. 2015, 34, 649-654. [CrossRef]

33. Sasaki, Y.; Hirooka, Y.; Kawashima, H.; Ishikawa, T.; Takeshita, K.; Goto, H. Measurements of renal shear wave velocities in chronic kidney disease patients. Acta Radiol. 2017, 59, 884-890. [CrossRef] [PubMed]

34. Grosu, I.; Bob, F.; Sporea, I.; Popescu, A.; Sirli, R.; Schiller, A. Two-Dimensional Shear-Wave Elastography for Kidney Stiffness Assessment. Ultrasound Q. 2021, 37, I44-I48. [CrossRef]

35. Bob, F.; Grosu, I.; Sporea, I.; Bota, S.; Popescu, A.; Sima, A.; Şirli, R.; Petrica, L.; Timar, R.; Schiller, A. Ultrasound-Based Shear Wave Elastography in the Assessment of Patients with Diabetic Kidney Disease. Ultrasound Med. Biol. 2o17, 43, 2159-2166. [CrossRef] [PubMed]

36. Liu, Q.-Y.; Duan, Q.; Fu, X.-H.; Fu, L.-Q.; Xia, H.-W.; Wan, Y.-L. Value of elastography point quantification in improving the diagnostic accuracy of early diabetic kidney disease. World J. Clin. Cases 2019, 7, 3945-3956. [CrossRef] [PubMed]

37. Stock, K.; Klein, B.; Cong, M.V.; Regenbogen, C.; Kemmner, S.; Büttner, M.; Wagenpfeil, S.; Matevossian, E.; Renders, L.; Heemann, U.; et al. ARFI-based tissue elasticity quantification and kidney graft dysfunction: First clinical experiences. Clin. Hemorheol. Microcirc. 20II, 49, 527-535. [CrossRef] [PubMed]

38. Arndt, R.; Schmidt, S.; Loddenkemper, C.; Grünbaum, M.; Zidek, W.; van der Giet, M.; Westhoff, T.H. Noninvasive evaluation of renal allograft fibrosis by transient elastography-A pilot study. Transpl. Int. 2oIo, 23, 87I-877. [CrossRef] [PubMed]

39. Syversveen, T.; Brabrand, K.; Midtvedt, K.; Strøm, E.H.; Hartmann, A.; Jakobsen, J.A.; Berstad, A.E. Assessment of renal allograft fibrosis by acoustic radiation force impulse quantification-A pilot study. Transpl. Int. 2oro, 24, 100-105. [CrossRef]

40. Lee, J.; Oh, Y.T.; Joo, D.J.; Ma, B.G.; Lee, A.L.; Lee, J.G.; Song, S.H.; Kim, S.U.; Jung, D.C.; Chung, Y.E.; Kim, Y.S. Acoustic Radiation Force Impulse Measurement in Renal Transplantation: A Prospective, Longitudinal Study With Protocol Biopsies. Medicine 2015, 94, eI59o. [CrossRef]

4I. Grenier, N.; Poulain, S.; Lepreux, S.; Gennisson, J.-L.; Dallaudière, B.; Lebras, Y.; Bavu, E.; Servais, A.; Meas-Yedid, V.; Piccoli, M.; et al. Quantitative elastography of renal transplants using supersonic shear imaging: A pilot study. Eur. Radiol. 2o12, 22, 2138-2146. [CrossRef]

42. Lukenda, V.; Mikolasevic, I.; Racki, S.; Jelic, I.; Stimac, D.; Orlic, L. Transient elastography: A new noninvasive diagnostic tool for assessment of chronic allograft nephropathy. Int. Urol. Nephrol. 2or4, 46, I435-I440. [CrossRef]

43. Nakao, T.; Ushigome, H.; Nakamura, T.; Harada, S.; Koshino, K.; Suzuki, T.; Ito, T.; Nobori, S.; Yoshimura, N. Evaluation of Renal Allograft Fibrosis by Transient Elastography (Fibro Scan). Transplant. Proc. 2015, 47, 640-643. [CrossRef]

44. Leong, S.S.; Wong, J.H.D.; Shah, M.N.M.; Vijayananthan, A.; Jalalonmuhali, M.; Chow, T.K.; Sharif, N.H.M.; $\mathrm{Ng}, \mathrm{K} . \mathrm{H}$. Shear wave elastography accurately detects chronic changes in renal histopathology. Nephrology 202I, 26, $38-45$. [CrossRef] [PubMed]

45. Yang, X.; Hou, F.-L.; Zhao, C.; Jiang, C.-Y.; Li, X.-M.; Yu, N. The role of real-time shear wave elastography in the diagnosis of idiopathic nephrotic syndrome and evaluation of the curative effect. Abdom. Radiol. 2020, 45, 2508-2517. [CrossRef]

46. Wang, L.; Xia, P.; Lv, K.; Han, J.; Dai, Q.; Li, X.M.; Chen, L.M.; Jiang, Y.X. Assessment of renal tissue elasticity by acoustic radiation force impulse quantification with histopathological correlation: Preliminary experience in chronic kidney disease. Eur. Radiol. 2014, 24, 1694-1699. [CrossRef]

47. Bob, F.; Grosu, I.; Sporea, I.; Bota, S.; Popescu, A.; Sirli, R.; Petrica, L.; Schiller, A. Is there a correlation between kidney shear wave velocity measured with VTQ and histological parameters in patients with chronic glomerulonephritis? A pilot study. Med. Ultrason. 2or8, I, 27-3I. [CrossRef] [PubMed]

48. Hu, Q.; Zhang, W.; Lin, Z.-Q.; Wang, X.-Y.; Zheng, H.-Y.; Wei, H.-M.; He, H.-G. Combined Acoustic Radiation Force Impulse and Conventional Ultrasound in the Quantitative Assessment of Immunoglobulin a Nephropathy. Ultrasound Med. Biol. 2o19, 45, 2309-2316. [CrossRef] 
49. Asano, K.; Ogata, A.; Tanaka, K.; Ide, Y.; Sankoda, A.; Kawakita, C.; Nishikawa, M.; Ohmori, K.; Kinomura, M.; Shimada, N.; et al. Acoustic radiation force impulse elastography of the kidneys: Is shear wave velocity affected by tissue fibrosis or renal blood flow? J. Ultrasound Med. 2014, 33, 793-8or. [CrossRef] [PubMed]

5o. Grenier, N.; Gennisson, J.-L.; Cornelis, F.; Le Bras, Y.; Couzi, L. Renal ultrasound elastography. Diagn. Interv. Imaging 2013, 94, 545-550. [CrossRef] [PubMed]

5I. Locke, S. The Effect of Interstitial Pressure on Tumour Stiffness. Master's Thesis, Graduate Department of Medical Biophysics, University of Toronto, Toronto, ON, Canada, 20I4. Available online: https://tspace.library. utoronto.calTI $\backslash$ textgreater\{\}bitstream (accessed on I May 202I).

52. Gennisson, J.-L.; Grenier, N.; Combe, C.; Tanter, M. Supersonic Shear Wave Elastography of In Vivo Pig Kidney: Influence of Blood Pressure, Urinary Pressure and Tissue Anisotropy. Ultrasound Med. Biol. 2012, 38, 1559-1567. [CrossRef] [PubMed]

53. Liu, X.; Li, N.; Xu, T.; Sun, F.; Li, R.; Gao, Q.; Chen, L.; Wen, C. Effect of renal perfusion and structural heterogeneity on shear wave elastography of the kidney: An in vivo and ex vivo study. BMC Nephrol. 2or7, I8, 265. [CrossRef]

54. Grosu, I.; Bob, F.; Sporea, I.; Popescu, A.; Schiller, A. Assessment of Renal Vein Thrombosis using Renal Acoustic Radiation Force Impulse (ARFI) Imaging in a Systemic Lupus Erythematosus (SLE) patient: A case report. In Proceedings of the I7th National Conference of the Romanian Society of Ultrasound in Medicine and Biology, Timisoara, Romania, I5-17 May 2014.

55. Bob, F.; Grosu, I.; Sporea, I.; Timar, R.; Lighezan, D.; Popescu, A.; Sirli, R.; Buzas, R.; Petrica, L.; Munteanu, M.; et al. Is Kidney Stiffness Measured Using Elastography Influenced Mainly by Vascular Factors in Patients with Diabetic Kidney Disease? Ultrason. Imaging 2018, 40, 300-309. [CrossRef] [PubMed]

56. Çildağ, M.B.; Gök, M.; Abdullayev, O. Pre-procedural shear wave elastography on prediction of hemorrhage after percutaneous real-time ultrasound-guided renal biopsy. Radiol. Med. 2020, I25, 784-789. [CrossRef] [PubMed]

57. Wang, Y.; Feng, Y.; Yang, X.; Zhang, L.; Zhang, T.; Wang, W. Clinical Values of Studying Kidney Elasticity with Virtual Touch Quantification in Gestational Hypertension Patients. Med. Sci. Monit. 2016, 22, 403-407. [CrossRef]

58. Garcia, S.R.M.; Grossmann, M.; Lang, S.T.; Trong, M.N.; Schultz, M.; Guo, J.; Hamm, B.; Braun, J.; Sack, I.; Tzschätzsch, H. Full-Field-of-View Time-Harmonic Elastography of the Native Kidney. Ultrasound Med. Biol. 2018, 44, 949-954. [CrossRef]

59. Grossmann, M.; Tzschätzsch, H.; Lang, S.T.; Guo, J.; Bruns, A.; Dürr, M.; Hoyer, B.F.; Grittner, U.; Lerchbaumer, M.; Trong, M.N.; et al. US Time-Harmonic Elastography for the Early Detection of Glomerulonephritis. Radiology 2019, 292, 676-684. [CrossRef]

6o. Leong, S.S.; Wong, J.H.D.; Shah, M.N.M.; Vijayananthan, A.; Jalalonmuhali, M.; Sharif, N.H.M.; Abas, N.K.; Ng, K.H. Stiffness and Anisotropy Effect on Shear Wave Elastography: A Phantom and in Vivo Renal Study. Ultrasound Med. Biol. 2020, 46, 34-45. [CrossRef] [PubMed]

6I. Wang, L. New insights on the role of anisotropy in renal ultrasonic elastography: From trash to treasure. Med. Hypotheses 2020, I43, IIOI46. [CrossRef]

62. Correas, J.-M.; Anglicheau, D.; Joly, D.; Gennisson, J.-L.; Tanter, M.; Hélénon, O. Ultrasound-based imaging methods of the kidney-Recent developments. Kidney Int. 2o16, 90, II99-I2Io. [CrossRef] [PubMed]

63. Bruce, M.; Kolokythas, O.; Ferraioli, G.; Filice, C.; O’Donnell, M. Limitations and artifacts in shear-wave elastography of the liver. Biomed. Eng. Lett. 2or7, 7, 8I-89. [CrossRef] [PubMed]

64. Barr, R.G. Can Accurate Shear Wave Velocities Be Obtained in Kidneys? J. Ultrasound Med. 2019, 39, I097-IIO5. [CrossRef] [PubMed]

(C)202 Copyright by the author. Licensed as an open access article using a CC BY 4.0 license.

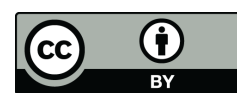

